University for Business and Technology in Kosovo

UBT Knowledge Center

UBT International Conference

2013 UBT International Conference

Nov 2nd, 12:45 PM - 1:00 PM

\title{
Tirana, Between East And The West In The Focus Of The Urban Texture
}

Armand Vokshi

Polytechnic University of Tirana, armandvokshi@gmail.com

Ani (Panariti) Tola

Polytechnic University of Tirana, ani.panariti@fau.edu.al

Follow this and additional works at: https://knowledgecenter.ubt-uni.net/conference

Part of the Architecture Commons

\section{Recommended Citation}

Vokshi, Armand and Tola, Ani (Panariti), "Tirana, Between East And The West In The Focus Of The Urban Texture" (2013). UBT International Conference. 17.

https://knowledgecenter.ubt-uni.net/conference/2013/all-events/17

This Event is brought to you for free and open access by the Publication and Journals at UBT Knowledge Center. It has been accepted for inclusion in UBT International Conference by an authorized administrator of UBT Knowledge Center. For more information, please contact knowledge.center@ubt-uni.net. 


\title{
Tirana, Between East And The West In The Focus Of The Urban Texture
}

\author{
Armand Vokshi ${ }^{1}$, Ani Tola (Panariti) ${ }^{1}$, \\ ${ }^{1}$ Faculty of Architecture and Urbanism, Politecnic University, Albania \\ armandvokshi@gmail.com \\ ani.panariti@fau.edu.al
}

\begin{abstract}
This research tries to synthesize the urban development of Tirana, especially in the historical part of it, at different times. The evolution of the city of Tirana is a typical evolution for Albanian cities with an urban structure, which was born in the Ottoman period. The chaotic urban structure shaped spontaneously in recent centuries, in Bosios plan during 1940, was thought to be treated as a "garden city", well integrated with the new form of the city, preserving at the same time his physiognomy. Unfortunately this project has not been taken into consideration during the years of socialist realism, while in urban level there was no clear space developments in these parts. The situation in our time appears tragic with the destruction of the old urban structure but not in favor of a clear urban regulation for the city. The result of this paper is to identify and to dismantle the aggravated problems ofurban structure in the capital and show effectively intervenes in special cases.
\end{abstract}

Keywor ds: urban design, Tirana, Bosio, urban plan, urban texture

\section{Introduction}

In January 1920 at Lushnja congress in a compromise between the north and south of the country was decided the formation of a provisional (technical) government, which decreed Tirana as the temporary capital of Albania. After climbing to the top of the Albanian government in 1925, Ahmet Zogu decide to confirm Tirana as the new capital of Albanian state. At this point the challenges were enormous, needs to designed almost from scratch over existing tracks a typical oriental town, a capital-city with lear urban structure and equipped with a suitable network infrastructure.

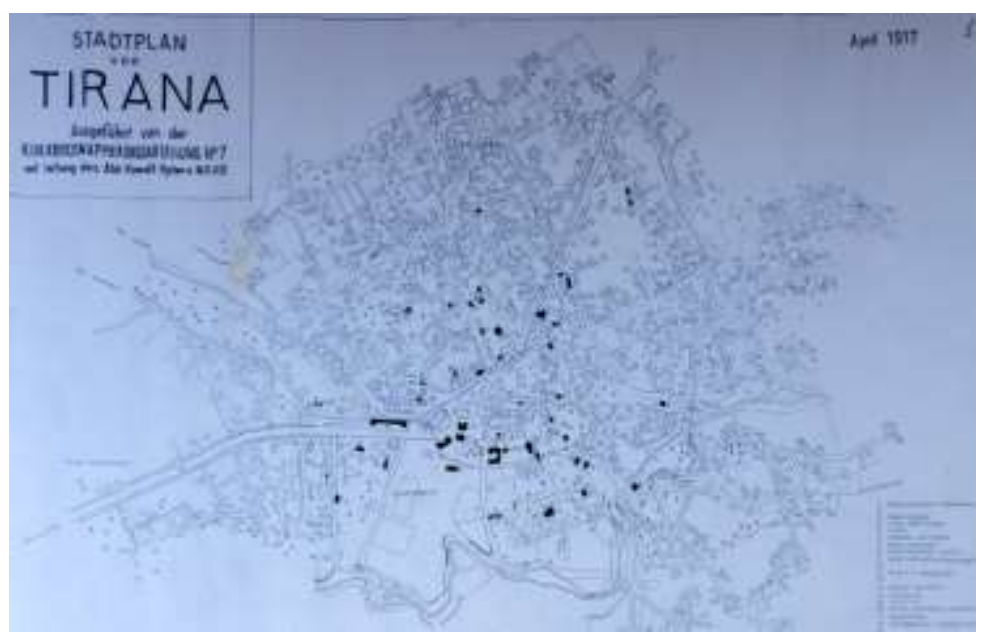

Fig. 1. Tirana plan, in 1917(Central Technical Archive of Construction, Tirana)

With a perfect geographical position, on a national road junction north-south, not far from the port of Durres in the west, the landscape of the Dajti Mount dominant east, Tirana was for the moment the most appropriate place to accommodate the governmental structures 


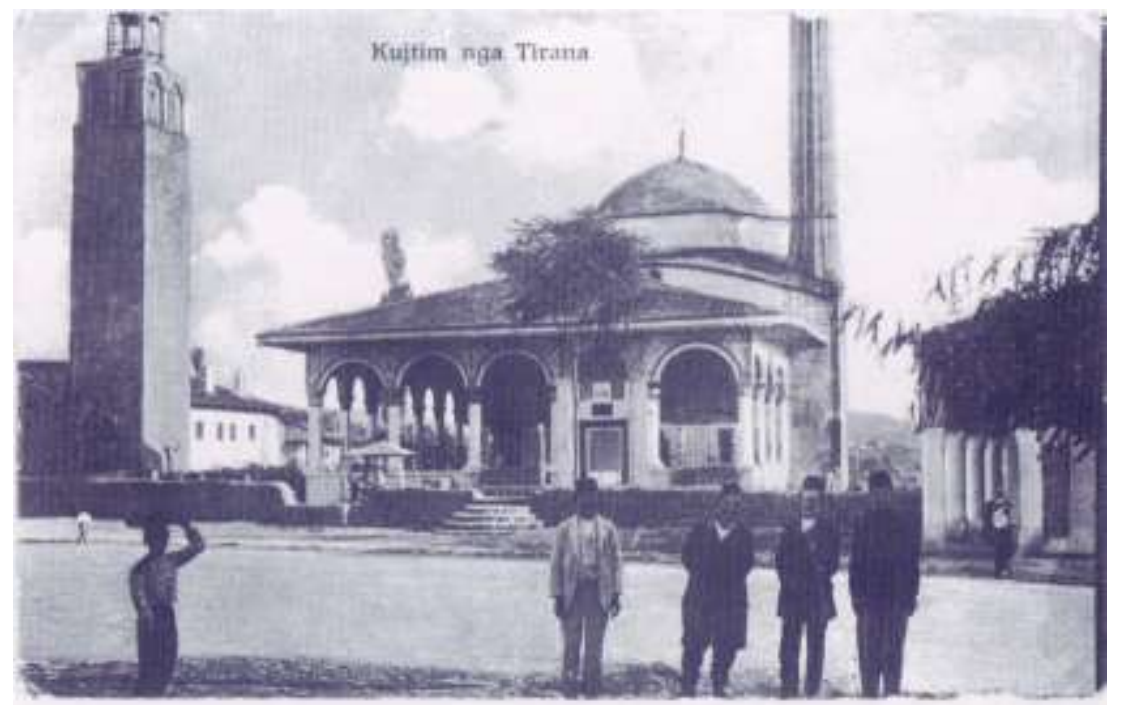

Fig. 2. Ethem Bey Mosque in 1921 (Archive of Marubi)

of the new state. According to various demographic data, the estimated population was of 12000 inhabitants in 1920, after migrations towards the new capital was increased by 30000 inhabitants in the census of 1930 and was estimated in 1945 about 60000 inhabitants. According to historians, the city was founded in 1614 by Sulejman Bargjini who built a mosque, a hammam and an inn, creating the first urban nucleus of Tirana. In subsequent years, around the complex, the city began to spread spontaneously by principles of mus lim Ottoman cities.

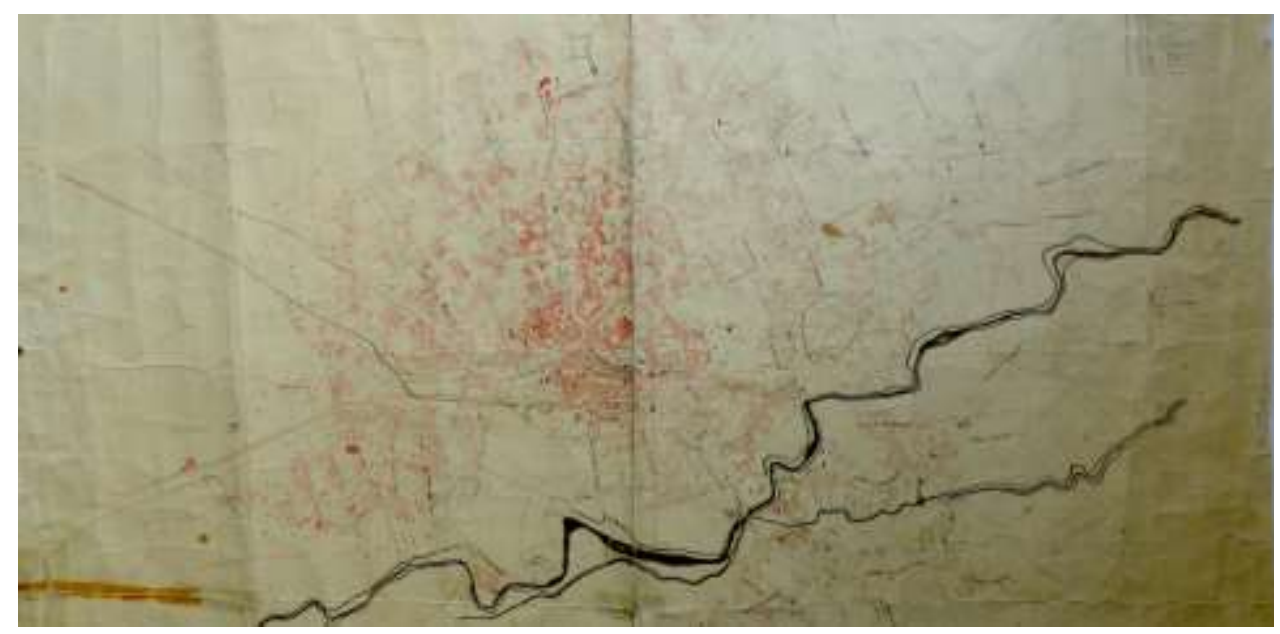

Fig. 3. Tirana plan in 1921 (Central Technical Archive of Construction, Tirana)

\section{Paper Preparation}

Observed from above, the city looked like an agglomeration of steep roofs and adobe walls painted in white. The repeating Game of these roofs change with the presence of religious public facilities like Islamic or Catholic-Orthodox. Ethem Bey Mosque and the Clock Tower as a complex was very important for the city, which in urban interventions for the development of the capital Tirana, will become part of the existing urban connectors and determining new shape.

Urban development of trade and craft part of the Old Bazaar, close to the $t$ Ethem Bey Mosque and the Clock Tower complex, divided Tirana into two parts: in the north and east part of the housing consists 
of simple constructions, in most with adobe and south-west it's trade and craft production, where streets and squares system was an integral part of the city with a vernacular character.

So, the moment of naming the capital, Tirana represent a typical oriental structure, where the existing urban texture, regarded by many as the "garden city", should quickly vacate space for the structures of the state government, non-existent at that time.

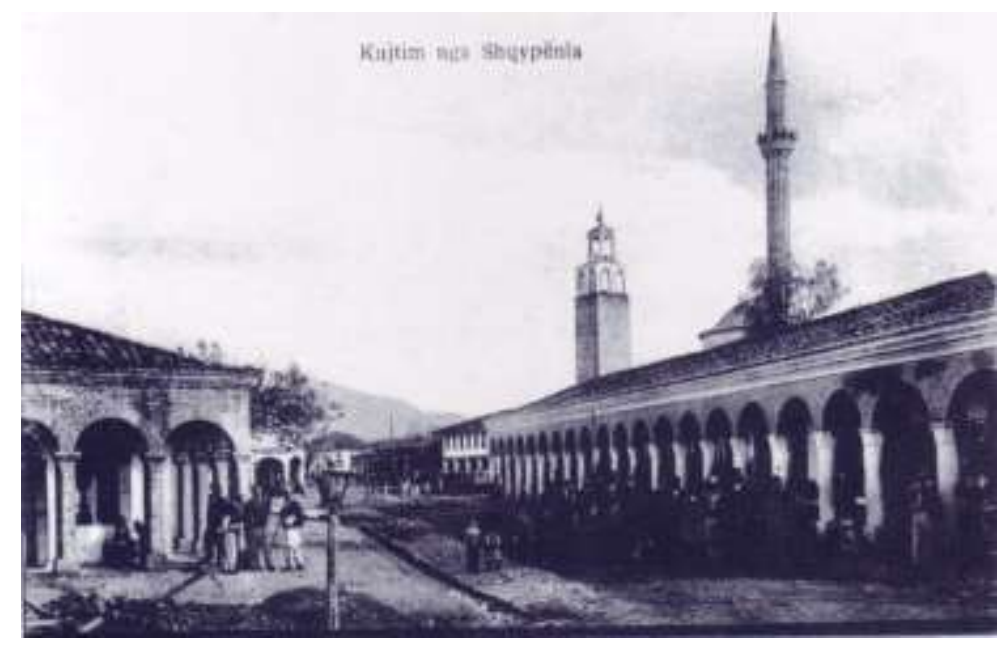

Fig. 4. Tirana Bazaar in 1921

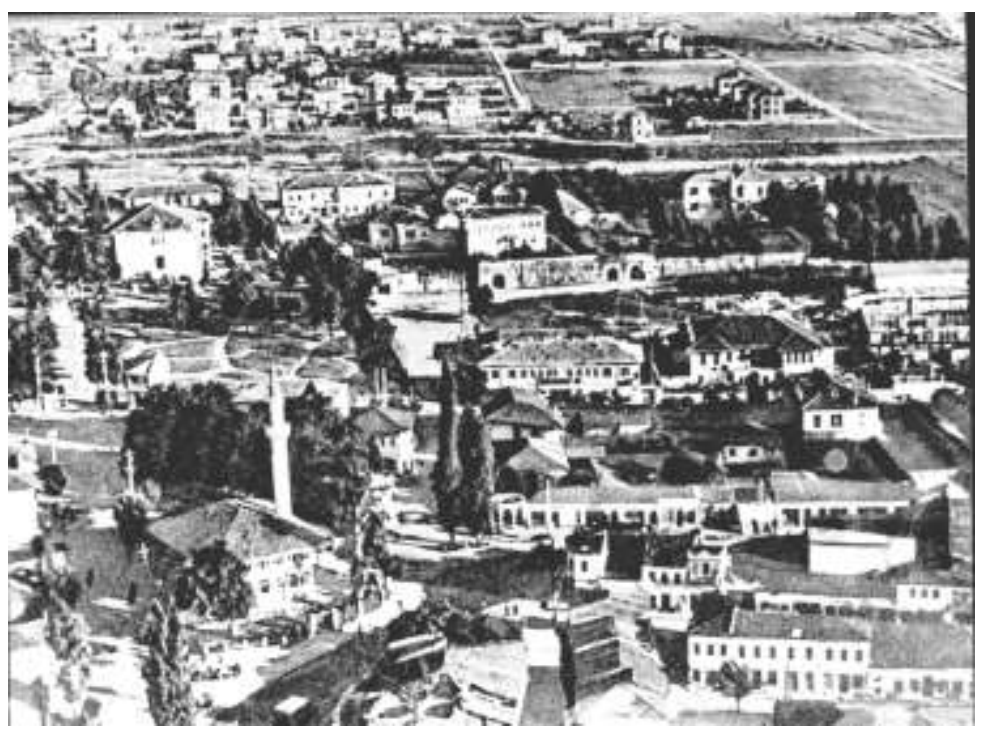

Fig. 5. The aerial view of Tirana in 1925

At the same time, should face the inevitable growth and expansion of the city, as a result of demographic population setbacks. The new state bureaucrats, various traders and workers were directed to Tirana with the hope of a better life, for this situation were urgently required new space for residential and commercial environments.

After all those centuries under Ottoman occupation, economic and cultural projection of the future, for the Albanian leadership class was natyrally oriented westward. For this reason, their demands were clear in the political and economic, but also in urban and architectural view of the territory. Ahmet Zog, Albania's prime minister at 1925 , in a delicate political situation, while in Italy was consolidated fascist regime, was forced to practice a policy more favorable to the Italian State and the Italian capital. [1] Where would require to Mussolini parallel professional help for engineers, architects and urbanists of 
"high level" to develop a regulatory plan refined and competent for the new capital and with significant interference in Albanian territory.

This negotiation process allowed the creation of the Albanian NationalBank, as well as creation of Svea (Albanian Economic Development Society) which would ensure that funds lent by Italy will be spent in public works and for the implementation of the regulatory plan of Tirana which will projected by the Roman architect Armando Brazini [2].

Brazini embodies a classic architect who brought from his homeland an architectural language inspired by the monumental tradition of Roman baroque, which were transplan ted without any change in Tirana, in a very different context from both Italian and the European one.

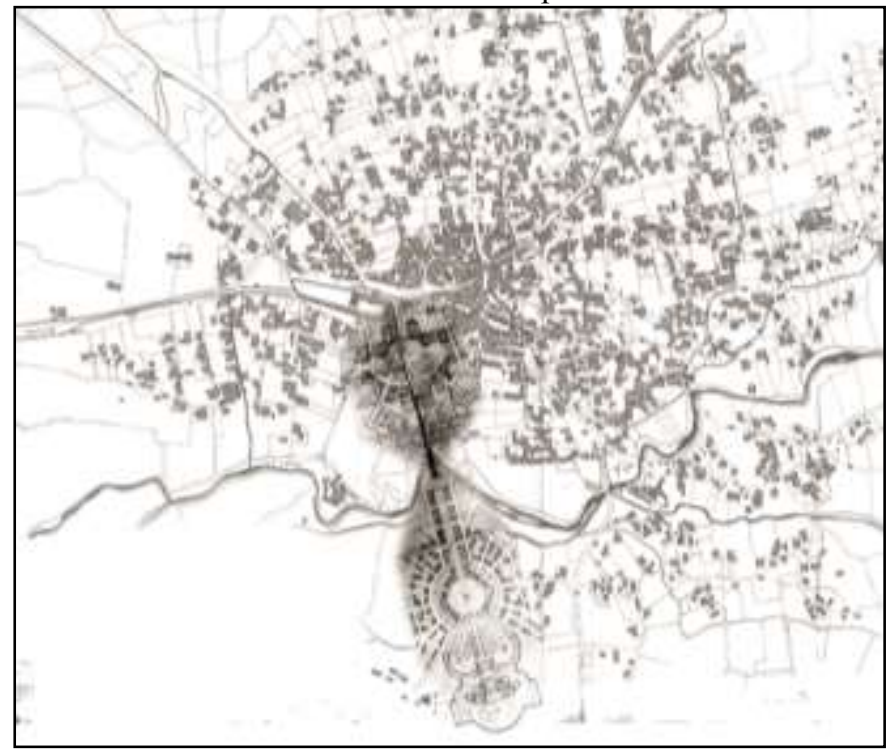

Fig. 6. The montage of Brazini plan in 1925

Brazini [3] idea for the new center of the Albanian capital, where taste and oriental presence was strong enough, it was a considerable axial radical intervention on the urban texture and that would mean a strong linear cracks that would serve as monumental boulevard of the main city's. The orientation of this avenue should be according to the axis north - south, interventions characteristic of the ancient Romans in their colonies performed according to the principle "cardo maximus", shifted light from the west. In fact, a good part of boulevard will developed on an agrarian territory, fragmented by Lana river, part of which was proposed by Ahmet Zog as suitable area for the urban expansion to the new capital. [4]

This boulevard is a coordinator axis for urban development and a capacitor for the new centralization, with varying degrees. The prospects for the new squares were attached to the regulatory plan, it's monumental central of ministries, the Skanderbeg Square and final the Presidential Palace. Boulevard trail enters to the city through an important point that is Skanderbeg Square, which was transformed in the main axis of the new urban image. Major breakdowns required to implement the new axis should leave the space of a monumental axis defined as the "heart" of the city lacked up to that time. The idea of the monumental central square derivative of colonial roman traditions had originated as "forum". In Roman cities, users generally found the angled intersection of "cardo maximus" with "decumanus maximus", in the east - west axis, where in the specific case of Tirana, decumanus forum is missing and at the intersection of cardos with radial roads coming from other cities. 


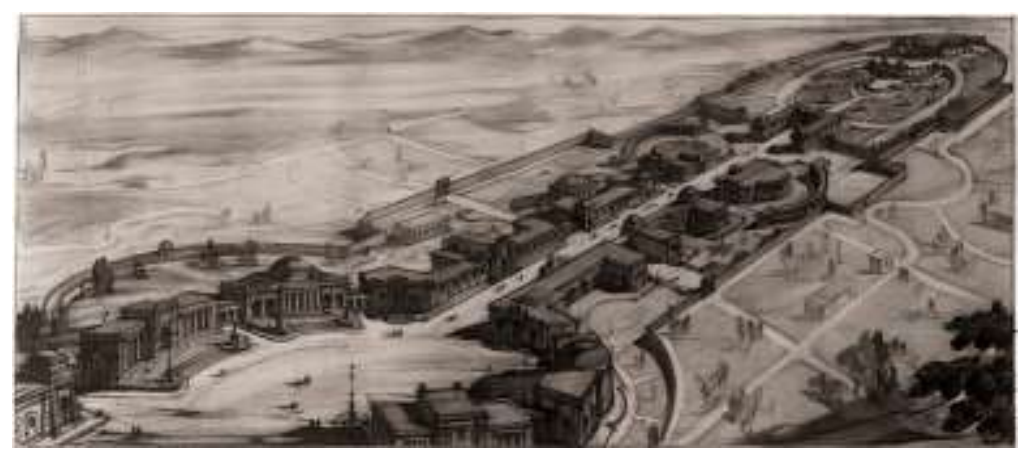

Fig. 7. The aerial perspective of Brasini plan (Archive of Brasini, Roma)

With this urban scenery, Tirana would have totally changed the image with strong architectural language cons equence of ancient Roman culture, in stark contrast with the existing city. The idea of large urban transformation, according to Brazini, also clarified in the demolition project regardless of existing buildings, replaced with the new government headquarters, administrative, cultural, characterized by a clear ornaments of Roman monumentality. [5] Major monumental axis was introduced as a way of broad and straight, almost entirely with portico and Doric columns, being updated with new items that came up or replace the existing part of the Ottoman city. These interventions organize open and collective space in the new axis and disposing on a monumental way the square near the mosque of Ethem Bey with the positioning of ministries. With the realization of a typical French geometric park on the easy slope to be extended at the entrance of the Presidential Palace will organized a panoramic area at the entrance of the city. Not so far from the Presidential Palace, Brazini projects a square surrounded by Administrative buildings organized by the planimetric view with a strong radial system and concentric circles. The aggravated report between Brazini 8 and Ahmet Zogu, probably due to project delays or different requirements from our part, resulted in the cancellation of the contract by Ahmet Zog. The project for the center of Tirana was not realized and Brazinit id eas were left on one side. After termination report with the Roman architect Armando Brasini, Ahmet Zogu, who then, in September 1928 will be elected king, to continue with the transformation work for the new Albanian capital, initially commis sioned Austrian architect Hans Köhler and Albanian engineer Skender Frashëri to deal with the new regulatory plan. 1 Later on to this group will join the Italian architect Florestano Di Fausto. This delicate is sue should certainly be continued where Brazini had left it.

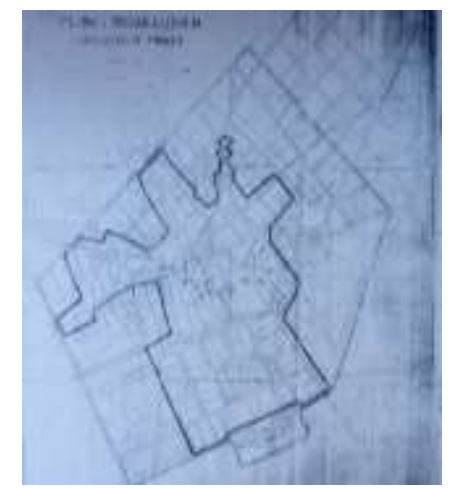

Fig. 8. Tirana plan in 1928-1930 (Central Technical Archive of Construction, Tirana)

The plan of 1928, after several options made earlier from those three, appeared as the first ever regulatory plan of Tirana. The main goal was the design and implementation of a superb infrastructural network, necessary to support expansion

and construction to the south west of the city. This area will serve as a territory reserve able to cope with demographic growth that the plan is required to precede, aiming in the future the population of the new capital will be doubled or trebled. [6] 


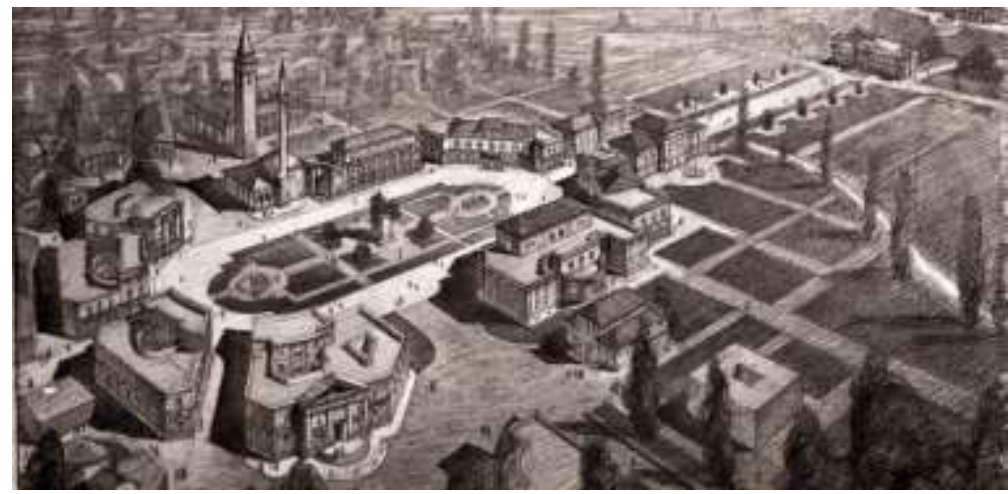

Fig. 9. The project for boulevard and Skanderbeg Square in 1928 (Archive of Florestano Di Fausto, Roma)

This plan, in its interventions, guarded and re-proposed Boulevard idea proposed by Brazini with newness the extension of the major axis to the north and also the central leveling therefore central ministries plaza already slightly redesigned. At the extremes of the boulevard were respectively large monumental squares. This intervention required major breach in the existing radical character of the city.

Strolling towards the main square was reserved for three typical French dressing parks, with 300 and 200 meters, which did configured geometrically in full symmetry by the main axis of the boulevard. On the opposite side of the royal palace, in the north of the boulevard was supposed to be established the city stadium, after the clear split that the radical axis make to the existing Ottoman city.

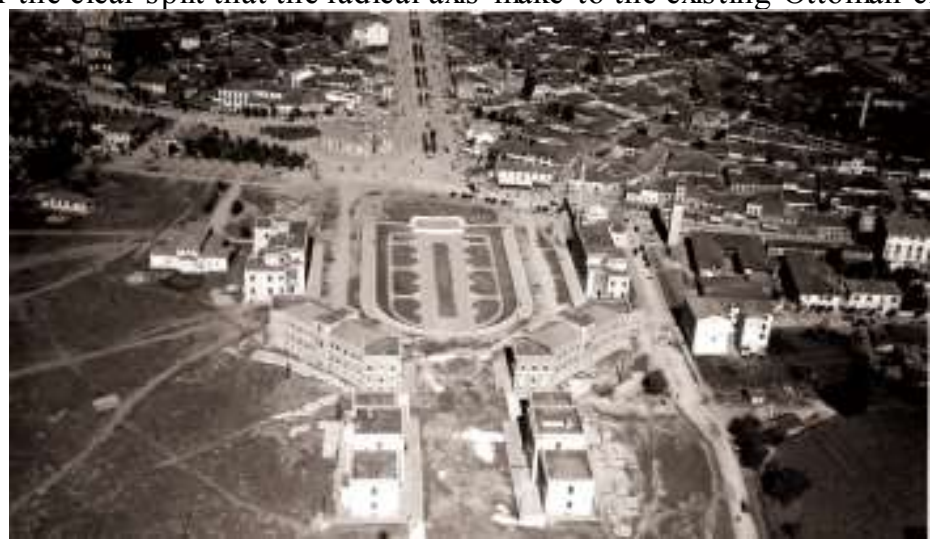

Fig. 10. A erial photo of the main square in 1936 (Archive of IGM, Firenze)

The plan proposed nearly a quadratic road system for the entire city and somehow respected major introductory axes derive from other cities to reaching the center, the new Skanderbeg Square.

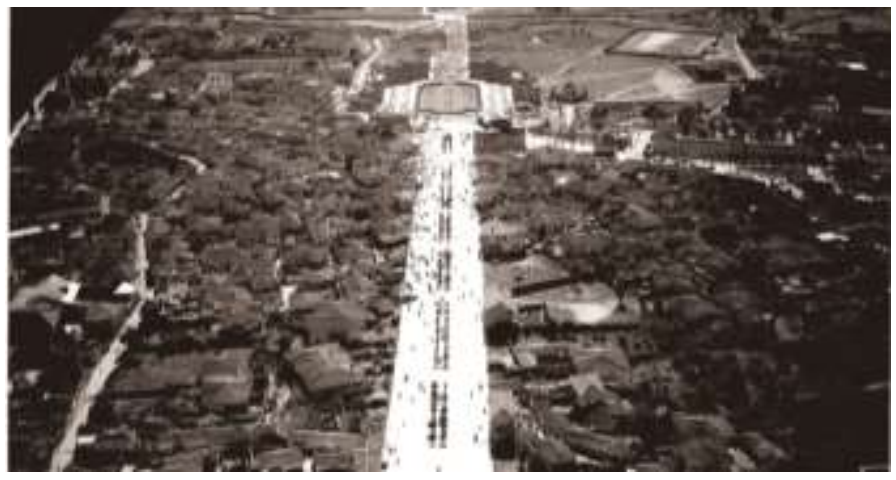

Fig. 11. Aerial photo of Skenderbej square, in 1936 (Archive of IGM, Firenze) 
Very important was the provision make by the plan for the city in the south-west with the new quarter 'Tirana e Re', whose territories were taken from the disposition thought that would be made to the Lana River and from agricultural territories. To the symmetric rectangular scheme of this new urban part was put in a large park as well symmetrical as the axis of Tellini Boulevard, parallel to the major boulevard. Fascist military intervention in 1939 finds the city which extended more and more like an oil slick, where new buildings are occupied the place of the old ones, or very old buildings adapted rapidly, barracks and buildings looked everywhere.

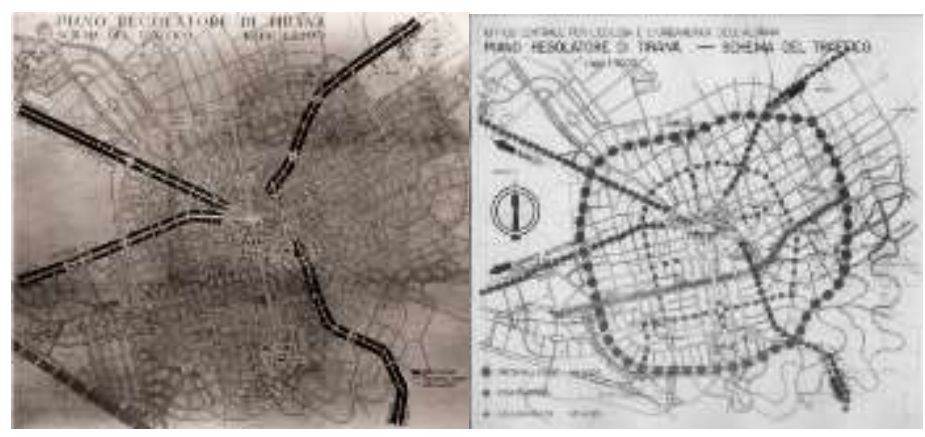

Fig. 12. Scheme of the radial roads on the regulatory plan in 1939 (Archive of Bosio)

Fig. 13. Scheme of the ring roads on the regulatory plan in 1939 (Archive of Bosio)

With the major demographic movements, lack of housing and commercial space and insufficient road system caused a major urban crisis. To overcome this problem, it was designed a radial road network which converged in Skanderbeg Square, which the ministries houses were almost fully realized. More than any other city in Albania, Tirana needed a really Regulatory Plan.

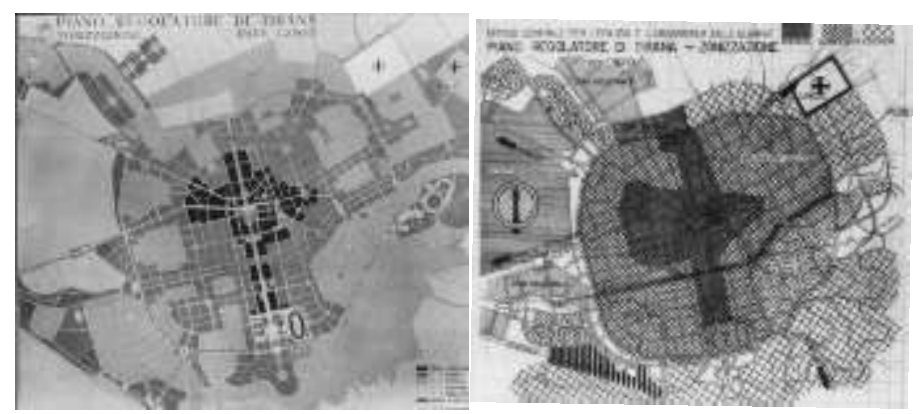

Fig. 14. Regulatory plan in 1939 (Archive of Bosio)

Fig. 15. Zoning of the regulatory plan in 1939 (Archive of Bosio)

Fascist government sends in Tirana a group of young architects led by Gherardo Bozio, which will deal with the Regulatory Plan of Tirana. Studies for the plan began in September 1939 with the design and later the realization of the square and the boulevard of the fascist ideology. In October of the same year, the work began for the plan idea of the regulatory plan which ended with a project plan approved by Law 71, on 7 March 1940. 


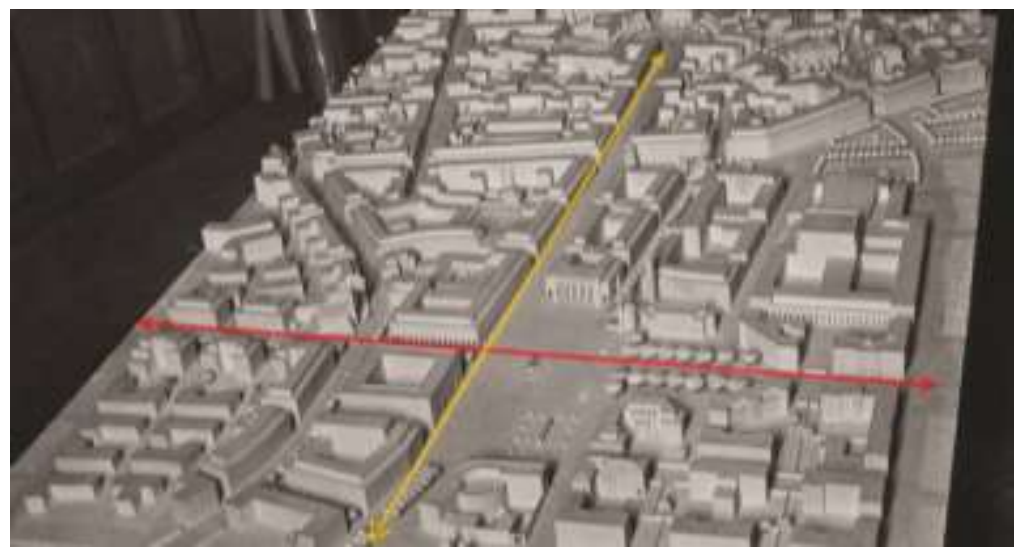

Fig. 16. The project's of the main square and old bazaar (Archive of Bosio)

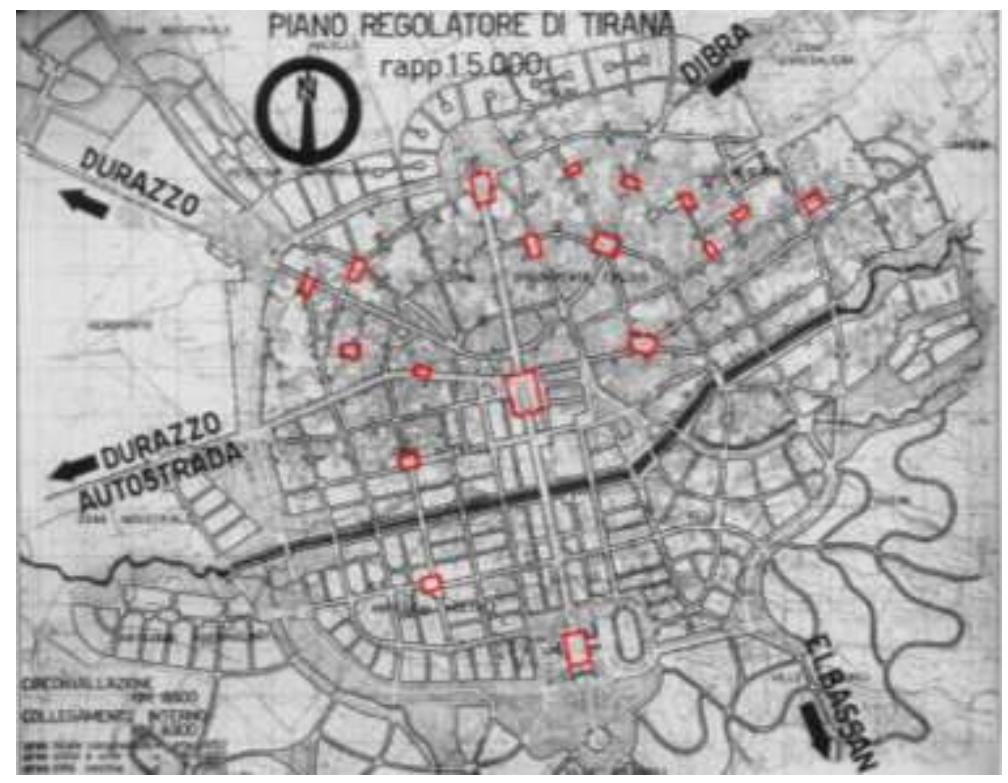

Fig. 17. Squares scheme, in 1939 (Archive of Bosio)

In 1938 began the studies on network road and urban and above all, also began the studies for the limited plan in the area between the street "Vittorio Emanuele III" (today "Zogu I") and the old road to Shkodra. A specific plan with some organic unity was prepared for the area called "Tirana e Re", which were included the Lana River to the south and the hill where today is the artificial lake and on the east from Elbasani road.

In appearance all buildings were irregular and varied as the derivative of rapid urban development.

Constructive and architectural features of buildings in the center were mainly oriental, with almost most of the buildings with only one floor and build in rammed earth ( qerpic) and crashed with few modern villas built up to that moment. According to Bosio private gardens gave the positive and picturesque notes, often very large, which presented through the narrow streets.

Tirana compared with other Albanians centers had no history of environmental characteristics of great importance to protect and preserve. Mosque of Ethem Bey, Old Mosque and the Bazaar was a valuable architectures that had such an interest to be considered important in determining the new plan.

In this plan Bosio interferes with caution, but with determination where compelling reasons of public interest, traffic, construction, hygiene and aesthetic element asked for. He was alert to the majority of existing buildings while maintaining a good portion of them, considering them almost entirely, without 
losing the idea that those objects which can then be presented discrete interest and texture to their decoration, can looked miserable when one day will be displayed in front of buildings that arise in the future, with great length and height to four, built according to the most modern and hygienic time.

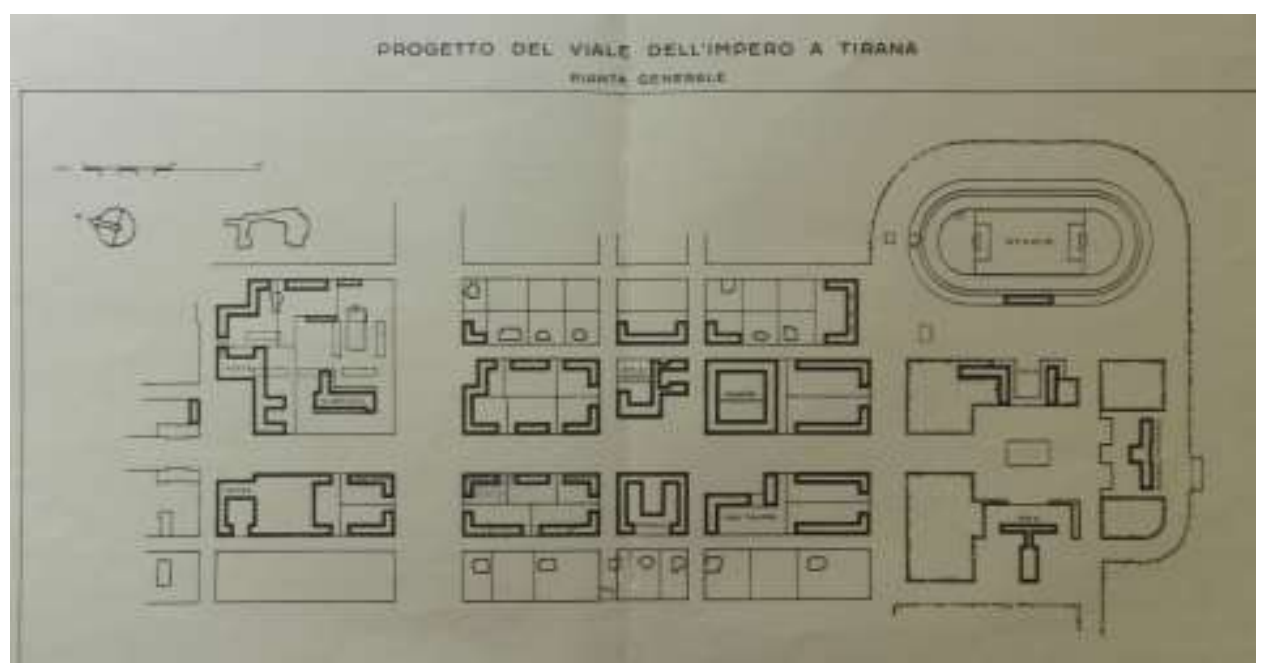

Fig. 18. Boulevard project, in 1939 (Archive of Bosio)

Many roads may seem sufficient for pedestrian and vehicle traffic at the time, was expanded and in some cases shifted when clearly seen that would have been totally inadequate for the heavy traffic that will created by the expansion of the city in the future, as well as introducing new ways of public and private transport. Regulatory plan foresaw the distribution of transit traffic outside the urban core, collecting from the directions of Durres, Shkodra, Elbasan and Dibra at the entrance of the city. With a total length of 8.111 kilometers, ring-shaped trajectory, consisting of two types of road structures: the tract stretching north-west and north-east, with a total width of 33 meters, the two roads form a central garden and were joined by wide sidewalks; the tract in south and south-west, with a total width of 42 meters, with a single central road accompanied by extensive gardens and a road for side service. In the period of communism, the following plans made from Italian like a detailed studies on the vision of the city, were not considered. Plans from 1957 to 1989 will be rerun with small parts of the Bosio plan.

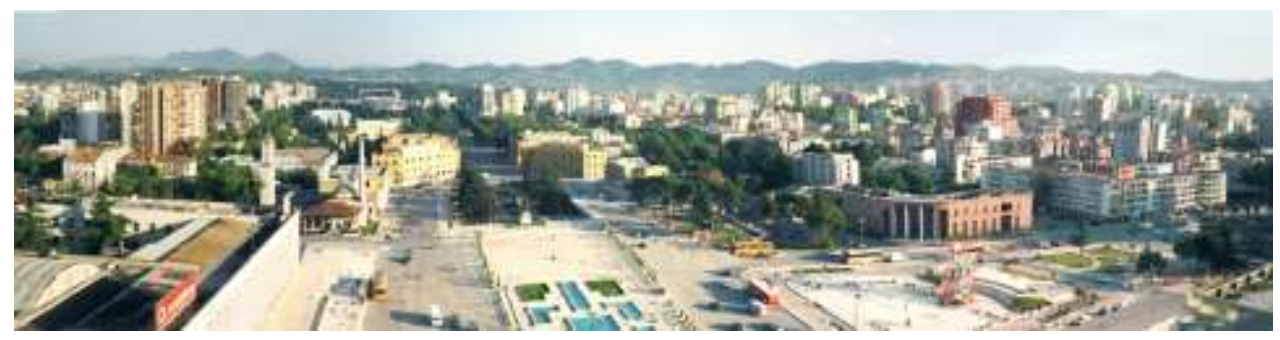

Fig. 19. The aerial view of Skanderbeg Square. (A.Vokshi) 


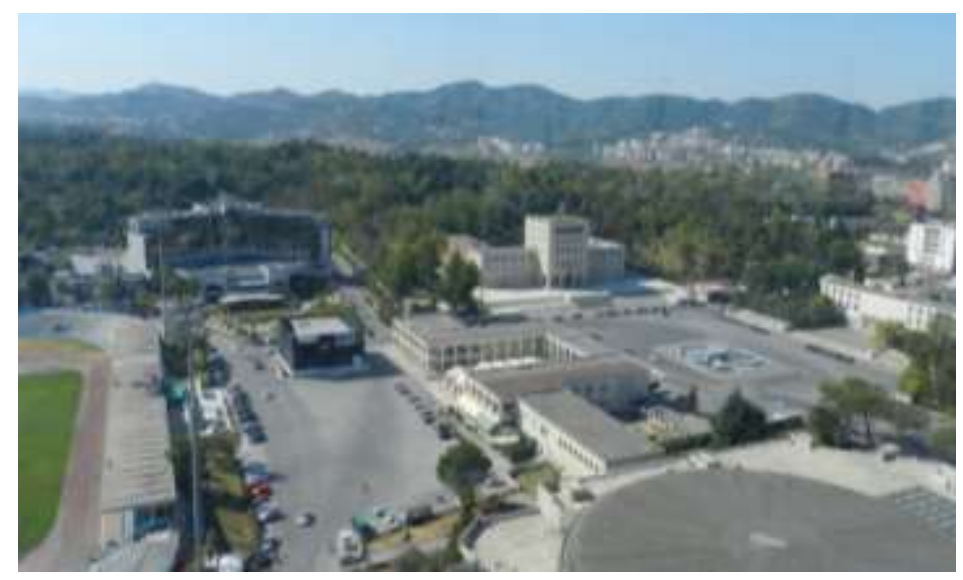

Fig. 20. Aerial view of Mother Teresa Square (A.Vokshi)

\section{Conclusions}

The intervention that Bosio provides for the existing old part of Tirana derive from some evidence that the architect himself will announce in it relation of the Regulatory Plan. This space considered by him as the "garden city", which had to canned in an integral way, first, as mentioned above, is the aes thetic factor and architectural forms with strong local scenic environment. Acording to himthese forms should be canned as well as a memory of the old city of Tirana and the old Ottoman texture should be integrated with the new primary road system and the logic of mini-centers small quarters with the corresponding squares evenly distributed in the territory. Bosio second argument in favor of their conservation is the relationship that citizens of Tirana had with their houses and a special way of life, seeing the whole problemalso by the social view. It would be difficult according to him for the citizens to adapt quickly to the new conditions. Another essential element considered by the architect is the economic factor needed to trans form large parts of the city already consolidated. Parts of the city look like that formally are consolidated; in reality they continue to follow their oriental and chaotic character, a part of to problems like marginalization and isolation of residents inside, and urban degradation of buildings. Even today seems that spatial quality worsened with the individual interventions around the objects which are performed at different times. Two perspectives can be addres sed in project operations; the money is intended that part of public interventions can play a key role in the activation of the regeneration processes on based sectors of the contemporary city. This will normally be made in relations with existing urban value, infrastructure networks and "urban porosity" necessary for recreational spaces.

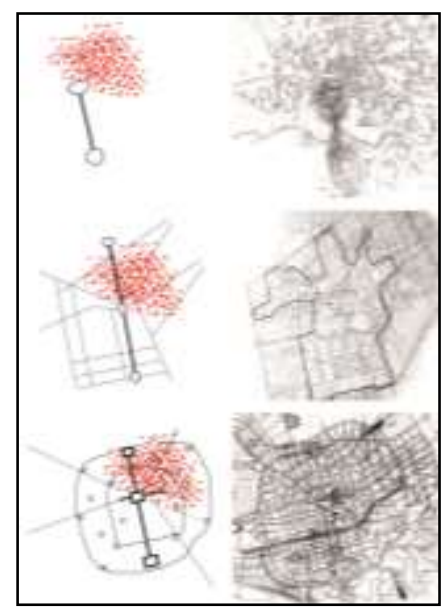

Fig 21 - schemes of three major plans in relation with the existing city of Tirana (A.Vokshi) 


\section{References}

1 Antonello BIAGGINI, Storia dell,Albania contemporanea, Milano, pp 63-81

2 F. Jocomoni Di San Savino, La politica dell'Italia in Albania nelle testimonianze del Luogotenente del Re, Cappelli Editore, p 25-37

3 M.A. Giusti, Albania, Architettura e Città, Maschietto Editore, Firenze, p 20

4 M.Giacomelli, A. Vokshi (a cura di), Architetti e ingegneri italiani in Albania, Edifir, Firenze, 2012

5 G. Gresleri, Albania: una dimensione sospesa tra opere pubbliche e rifondazione della città, in Architettura italiana d'oltremare Atalante Iconografico-a c. di G. Gresleri, P.G.

6 Massaretti, Bologna, Bolonia University Press, 2008, pp. 433-468.

7 M.A. Giusti, Albania, Architettura e Città, Maschietto Editore, Firenze, p 60 